where $x$ is $1 / V$, and $v$ denotes $n d^{2} / k, k$ being the mobility of the negative ion, and $d$ the distance between the electrodes. The velocity of the electron is assumed to be large in comparison with that of the ion. The fraction of electrons $(\theta)$ is a function of the impressed voltage and of the gas pressure.

The agreement of experiment with the above theory was established over a range of pressures from $7 \mathrm{~mm}$. to 1 atmosphere. The physical interpretation of the theory is that the great majority of negative ions are formed in the vicinity of the electrode at which the electrons originate; those electrons which do not give rise to negative ions near this electrode traverse in general the whole interval between the electrodes in the free state. Only an inconsiderable fraction of the ions, if any, can be formed by attachment in the body of the gas.

The values of $\theta$ in relation to the pressure and to the applied field have been obtained and will be given when the account of the experimental work is published in full.

E. M. WELLISH.

University, Sydney, June 26.

\section{Photosensitised Decomposition of Ozone by Bromine.}

As a result of work on the photochemical chlorineozone reaction carried out at King's College, London, ${ }^{1}$ experiments have been in progress on the bromine. ozone reaction in the hope of explaining the differences between the two reactions noted by Bonhoeffer ${ }^{2}$ and commented on by various authors since that time. It was found that chains of considerable length were produced in certain circumstances, and to account for this and other facts, the formation of an oxide of chlorine as an intermediate product was postulated.

It is suggested that the formation of a similar unstable oxide will account for the high quantum efficiency in the bromine-ozone reaction, and this receives support from work on the thermal process. ${ }^{3,4}$

Lewis and Schumacher ${ }^{3}$ concluded that it would be useless to attempt the $\mathrm{Br}_{2}-\mathrm{O}_{3}$ photo-reaction because of the many complicating factors, but preliminary experiments showed that the effect of the dark reaction could be minimised by working at atmospheric pressure with low concentrations of bromine and ozone and a large excess of oxygen. Working at $20^{\circ} \mathrm{C}$., the separation of any solid or liquid oxide is avoided, and the reaction appears to take place mainly in the gas phase. The natural dark reaction under these conditions is small for the first few hours, and can be partly eliminated by using balanced cells. ${ }^{2}$ A few preliminary results may be of interest at this stage.

A high quantum efficiency is obtained of the same order as that found by Bonhoeffer, who bubbled his $\mathrm{O}_{2}-\mathrm{O}_{3}$ mixture through liquid bromine before insolating with blue light.

As a general rule, there is no after-effect, indicating that little or no absorption of an intermediate compound on the walls is taking place in these experiments and this is also indicated by the fact that no appreciable change in transmission of $365 \mu \mu$ or $546 \mu \mu$ takes place on insolation. However, it is probable that this depends on the nature of the surface. The $\mathrm{Br}_{2}-\mathrm{O}_{3}$ photochemical action differs from the $\mathrm{Cl}_{2}-\mathrm{O}_{3}$ reaction in that there is no increase in rate of decomposition while the last few millimetres of ozone are being decomposed. 5,1

A further difference is that the quantum efficiency at $546 \mu \mu$ is practically equal to that for $365 \mu \mu$, although the wave-lengths correspond to absorption in the band and continuous regions respectively. (Compare Jost and Jung in the $\mathrm{H}_{2}-\mathrm{Br}_{2}$ photo-reaction.) $)^{6}$

Experiments indicate a direct proportionality of rate to intensity in the region covered, and approxim ately the same quantum efficiency is obtained for mixtures containing 0.3 to 3.3 per cent bromine and 0.5 to 4 per cent ozone.

In view of the above, it is considered that an oxide of bromine is the 'carrier' in both the thermal and photo reactions. Lewis ${ }^{4}$ indeed mentions this possibility, but inclines rather to the view that the carrier is an activated oxygen molecule, although the photo-decomposition of ozone scarcely supports this view.

Further experiments varying different factors are in progress with the view of elucidating both the thermal and photo-reactions. J. W. T. SPINKs.

University of Saskatchewan, Aug. 18.

1 Allmand and Spinks, Jour. Chem. Soc., 1652 ; 1931.

2 Bonhoeffer, Zeit. für Physik, 13, 94 ; 1923.

${ }^{3}$ Lewis and Schumacher, Zeit. physik. Chem., 6B, 423; 1930

- Lewis and Feitknecht, Jour. Am. Chem. Soc., 53, 2910; 1931.

${ }^{5}$ Weigert, Zeit. Elektrochem., 14, 591; 1908.

- Jost and Jung, Zeit. physik. Chem., 3, 83; 1929.

\section{Pottery with Flint Implements of Upper} Palæolithic Facies from Swanscombe, Kent.

Some time ago, ${ }^{1}$ there appeared in Nature a short account of a series of flint implements of Upper Palæolithic facies which I had found in a deposit, presumably of glacial origin, on Flamborough Head, Yorks. The cultural horizon of these implements was situated some six feet below ground-level and rested upon a layer of gravel.which, in its turn, capped the Upper Purple Boulder Clay.

Some months later, ${ }^{2}$ I announced my discovery of similar flint implements in the Brown Boulder Clay at Kirmington, Lincs, a deposit universally admitted as of glacial origin.

This year I located a similar series of flint implements, but associated with undecorated fragments of rough pottery, at Greenhithe, Kent. The site, which occupies a lateral valley, shows the following section :

G. Surface soil with ground-level at $50 \mathrm{ft} .2 \mathrm{ft} .0 \mathrm{in}$. above O.D.

F. Stony loam containing chalk frag- $6 \mathrm{ft} .0 \mathrm{in}$. ments and an occasional 'raft' of Coombe rock

E. Brickearth with implements and pot- $3 \mathrm{ft} .6 \mathrm{in}$. tery fragments

D. Sand with occupation-level at base . 6 in.

C. Gravel

B. Coombe rock. $\quad . \quad$. $\quad$. $5 \mathrm{ft} .0 \mathrm{in}$.

A. Chalk . . . . . . Plus.

Deposit E (the Brickearth) has been examined by Dr. R. H. Rastall, of Cambridge, who states that it is definitely not loess, but that it presents all the appearance of having been deposited by water action. The overlying stratum $\mathbf{F}$ (with its erratics, chalk fragments, and 'rafts' of Coombe rock) would seem to confirm the glacial origin of the implementiferous deposit of Flamborough Head previously described.

As a result of the generous assistance rendered by Mr. A. C. Davis, managing director of the Associated Portland Cement Manufacturers Co., Ltd., and the trustees of the Percy Sladen Memorial Fund, a series of excavations has been planned, reports on which will be published from time to time. The first excavation is well advanced, and a fine group of implements and pottery fragments has been recovered.

30 Southwick Street, W.2, J. P. T. BURCHELL.

No. 3230, VoL. 128] 